\title{
В.П. Срошенко
}

Харківський начіональний університет Повітряних Сил ім. І. Кожедуба, Харків

\section{МЕТОДИКА ВИБОРУ КОЕФІЦІЄНТІВ ДЛЯ ПОБУДОВИ КВАЛІМЕТРИЧНОЇ МОДЕЛІ ВИБОРУ ПОВІТРЯНОГО СУДНА ДЛЯ НАВЧАЛЬНОЇ ЛЬОТНОЇ ПІДГОТОВКИ}

Розкрита методика розробленого науково-методичного апарату оцінювання ступеню придатності конкретного типу повітряного судна до вирімення завдань навчальної льотної підготовки, та обтрунтування вибору типу літального апарату з наявних можливих альтернатив. Пропонується методика вибору коефічієнтів для побудови методу порівняльного оиінювання показників властивостей навчальнотренувальних літаків. Обгрунтовано варіант створення методики вибору раціонального типу навчальнотренувального літака для заміни існуючого парку повітряних суден авіачійних частин на основі порівняльної оцінки альтернативних варіантів зразків авіаційної техніки на світовому ринку авіаційної промисловоcmi.

Ключові слова: повітряне судно, кваліметричні моделі, ресурс, навчально-тренувальний літак, льотна підготовка.

\section{Вступ}

Парк навчально-тренувальних літаків (НТЛ) типу Л-39С, на яких в даний час проводиться навчальна льотна підготовка курсантів та підтримка льотних навичок льотного складу частин тактичної авіації, наближається до вичерпання призначених термінів експлуатації. Для забезпечення безперервності підготовки військових льотчиків постає актуальне завдання, пов'язане із визначенням конкретного типу НТЛ, на якому в подальшому буде здійснюватися підготовка льотного складу [1-3]. Це пов'язане 3 особливістю технології підготовки льотчика на бойовий літак, що стоїть на озброєнні, та обранням оптимального варіанту повітряного судна в існуючій авіаційній промисловості Державних підприємств України, а також іноземного виробництва. Пояснюється це стрімким зростанням тенденції погіршення кількісно-якісного стану парку навчальнобойових літаків, яка обумовлена вичерпанням, вже у свій час подовжених, призначених термінів служби, що в свою чергу створює передумови до втрати державою спроможності у власній підготовці льотчиків для тактичної авіації.

Аналіз останніх досліджень і публікацій. Аналіз сучасного стану науково-методичного апарату порівняльного оцінювання різних типів НТЛ та сучасних вимог, що виставляються до такого апарату, дозволив виявити наступні невідповідності, а саме: неврахування в існуючих методичних підходах мети функціонування НТЛ в системі навальної льотної підготовки (НЛП); відсутність чітких критеріїв оцінювання та вибору типу літака; недостатне врахування прояву воєнно-технічних та воєнноекономічних факторів в побудові критеріїв оціню- вання властивостей типу НТЛ; відсутність кваліметричних моделей властивостей НТЛ і льотною підготовкою [7]. Ця невідповідність призводить до низького рівня ступеню грунтовності рішень, що приймаються при плануванні розвитку парку авіаційної техніки (АТ) навчальних авіаційних частин та породжує наявність актуального та важливого для практики наукового завдання, що полягає у необхідності удосконалення методики порівняльного оцінювання варіантів навчально-бойового літака на основі поглиблення іiі системності за рахунок врахування ступеню пристосованості літака до вирішення завдань навчальної льотної підготовки, а також прояву воєнно-технічних та воєнно-економічних факторів при виборі шляхів оновлення парку АТ навчальних авіаційних частин [4-6].

Важливою складовою тут $є$ існуючий парк навчально-тренувальних літаків 3 фактором стрімкого вичерпання призначеного строку служби (рис. 1).

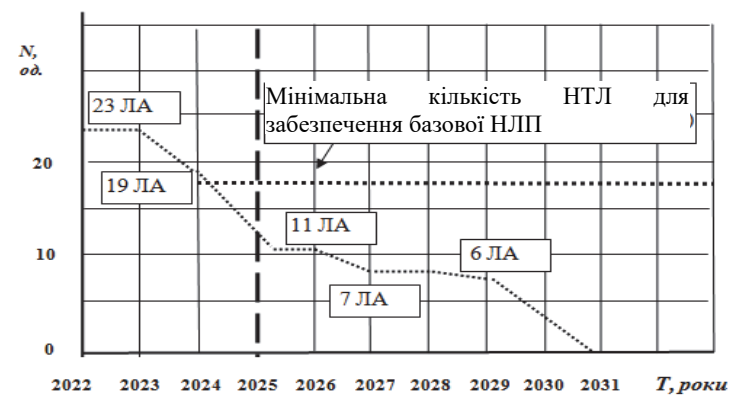

Рис. 1. Динаміка чисельності парку навчальних літаків авіаційної частини за фактором вичерпання призначеного строку служби по роках Джерело: розроблено автором. 
Як витікає з наведеного аналізу сучасного стану наявного парку літаків типу Л-39С, зміна його кількісно-якісного складу на перспективі, 3 прогнозом до 2025 року, обумовлена вичерпанням призначених показників наявними виробами літальних апаратів даного типу, а саме призначеного ресурсу та призначеного строку служби, після завершення яких експлуатація наявної авіаційної техніки повинна бути припиненою незалежно від їх технічного стану [10]. Якщо вичерпання призначеного строку служби є об'єктивним чинником, то вичерпання призначеного ресурсу буде залежати від інтенсивності експлуатації навчально-тренувальних літаків. В свою чергу, така інтенсивність обумовлюється перспективним складом тактичної авіації Повітряних Сил 3С України, початковими умовами (ступенем укомплектованості стройових авіаційних частин екіпажами), рівнем ротації льотного складу в стройових частинах, і як наслідок, загальними обсягами замовлення на підготовку курсантів-льотчиків та його розподілом по роках, а також періоду, на який здійснюється прогнозування.

Існуючий дисбаланс між існуючими методичними підходами льотної підготовки і відсутністю чітких критеріїв оцінювання та вибору типу повітряного судна для такої підготовки, через брак кваліметричних моделей властивостей НТЛ і льотної підготовки, спонукає до створення методики порівняльного оцінювання варіантів навчального повітряного судна на основі поглиблення iі системності за рахунок врахування ступеню пристосованості літака до вирішення задач навчальної льотної підготовки, а також вибору шляхів оновлення парку повітряних суден. Це забезпечить зменшення факторів ризику у воєнно-технічних та воєнно-економічних розрахунках при виборі шляхів оновлення парку авіаційної техніки авіаційних частин в цілому [11-12].

Мета статті полягає в розробці методологічних підходів, спрямованих на підвищення ефективності заходів з оновлення парку авіаційної техніки авіаційних частин на основі обгрунтування вибору раціонального типу навчального повітряного судна 3 використанням критеріїв типу “ефективність - вартість".

\section{Виклад основного матеріалу}

Вирішення задач вибору методичного апарату порівняльного оцінювання варіантів навчальнотренувальних літаків, як відомо, в тому або іншому ступені пов'язане із розв'язуванням задачі порівняльного оцінювання альтернативних варіантів. На цей час відомо декілька методичних підходів до розв'язування такого роду задач стосовно порівняльного оцінювання зразків озброєння та військової техніки, зокрема бойової авіаційної техніки, до якої на повних підставах слід віднести й навчально- тренувальні літаки.

Одні відомі підходи базуються на безпосередньому порівнянні зразків між собою за сукупністю заздалегідь визначених їх тактико-технічних характеристик. Інші групи базуються на більш розширеному підході до порівняння - коли зразки розглядаються як елементи бойового авіаційного комплексу, тобто не тільки окремо функціонуючий зразок бойової авіаційної техніки, а й елементи потрібних систем наземного забезпечення (літак - система управління силами, система технічного забезпечення, включаючи інженерно авіаційне та аеродромнотехнічне забезпечення тощо). Третя група методичних підходів розглядає бойовий авіаційний комплекс як підсистему більш високого рівня ієрархіїбойову систему, тобто при оцінюванні враховується вплив зразків, які порівнюються, на кінцеву мету функціонування бойової системи в цілому [8-9].

Адже відомі методичні підходи до порівняльного оцінювання літальних апаратів військового призначення не дозволяють враховувати вплив властивостей зразка на ступінь придатності його до забезпечення виконання завдань навчальної льотної підготовки, тобто до головної мети використання зразка за призначенням - в системі льотної підготовки. Тут відсутні чіткі критерії порівняльного оцінювання НТЛ та критерії вибору (як правила винесення судження).

Проведений аналіз сучасного стану існуючого методичного апарату порівняльного оцінювання зразків повітряних суден свідчить про його недосконалість та обмежену придатність до розв'язування задач вибору типу НТЛ для заміни існуючого парку АТ авіаційних частин.

Аналіз виявленої невідповідності дозволив визначити напрями удосконалення методики порівняльного оцінювання різних типів повітряних суден та вибору критеріїв і показників властивостей НТЛ для використання у порівняльному оцінюванні літаків різних типів. Такий підхід має актуальність також в суміжних областях [13].

При побудові такого роду критеріїв в якості показників порівняльного оцінювання використовуються такі, що описують три основні комплексні властивості: результативність (корисний ефект), оперативність (витрати часу на досягнення потрібного ефекту та/або тривалість задоволення споживчих потреб), потрібні витрати ресурсів на отримання й використання бажаного ефекту. Стосовно порівняльного оцінювання різних типів НТЛ за ступенем пристосованості до виконання задач за призначенням показники властивостей літака повинні описувати ступінь досягнення ефекту по кожній групі завдань, для яких цей літак буде використовуватися, а саме не менш ніж: до виконання задач базової льотної підготовки (пропонується ввести узагальнений 
показник $K_{\text {нлn }}$ ) та ії складових (початкової та основної НЛП - пропонується ввести узагальнені показники $K_{\text {поч }}$ та $K_{\text {осн }}$, відповідно); до виконання покладених бойових завдань (знищення повітряних та наземних цілей) обрано відомі узагальнені показники - коефіцієнти бойового потенціалу, відповідно $K_{n о в}$ та $K_{\text {наз. }}$ Ця група показників в сукупності описуватиме результативність використання НТЛ.

В якості показників властивостей оперативності пропонується обрати узагальнюючий показник тривалості використання НТЛ за призначенням, що характеризується призначеним терміном служби літака, або призначеним наробітком (нальотом), після досягнення якого виріб АТ повинен бути знятим 3 експлуатації не залежно від його стану. За своєю суттю такий показник описує тривалість часу $\left(T_{c л}\right)$, за який він здатен приносити користь споживачеві. Для описання витрат ресурсів, потрібних на придбання та використання НТЛ за призначенням, обрано показник $S$, заснований на застосуванні відомого поняття типового розподілу вартості життєвого циклу повітряного судна по основних стадіях та етапах

За описаним вище фізичним змістом обраних показників, критерій порівняльного оцінювання різних типів НТЛ типу “ефективність-вартість” може набувати одного з нижче наведених виразів формалізованого виду:

$$
\begin{aligned}
& \alpha_{\text {поч }} K_{\text {поч }}+\alpha_{\text {осн }} K_{\text {осн }} \rightarrow \max ; \\
& K_{\text {пов }} \geq K_{\text {пов }}^{\text {зад }} \\
& K_{\text {наз }} \geq K_{\text {наз }}^{\text {зад }} \\
& S \leq S_{\text {зад }} \\
& T_{\text {сл }} \geq T_{\text {слзад }},
\end{aligned}
$$

де $\alpha_{\text {nоч}}, \alpha_{\text {осн }}$ - вагові коефіцієнти (відносна важливість) початкової та основної підготовки в системі НЛП курсантів; $K_{n o в}^{3 а д ~}, K_{\text {наз }}^{3 а д}, T_{\text {слад }}$ - задані порогові значення коефіцієнтів бойового потенціалу та призначеного строку служби (наробітку), відповідHо.

Другий вираз базується на мінімізації витрат та задоволенню обмежень на інші властивості:

$$
\begin{aligned}
& \alpha_{\text {поч }} K_{\text {поч }}+\alpha_{\text {осн }} K_{\text {осн }} \geq K_{\text {зад }} ; \\
& K_{\text {пов }} \geq K_{\text {пов }}^{\text {зад }} \\
& K_{\text {наз }} \geq K_{\text {наз }}^{\text {зад }} \\
& S \rightarrow \min \\
& T_{с л} \geq T_{\text {слзад }},
\end{aligned}
$$

де $K_{\text {слад }}$ - задане значення виваженої згортки показників пристосованості НТЛ до забезпечення виконання задач початкової та основної НЛП курсантів.

Третій вираз базується на ствердженні без застосування згортки показників призначення:

$$
\begin{aligned}
& K_{\text {поч }} \geq K_{\text {поч }}^{\text {зад }} \\
& K_{\text {осн }} \geq K_{\text {осн }}^{\text {зад }} \\
& K_{\text {пов }} \geq K_{\text {наз }}^{3 a d} \\
& K_{\text {наз }} \geq K_{\text {пов }}^{\text {зад }} \\
& S \rightarrow \min \\
& T_{с л} \geq T_{\text {слзад }}
\end{aligned}
$$

де $K_{n o ч}^{3 a d}, K_{o c н}^{3 a d}$ - задане значення показників пристосованості НТЛ до виконання задач початкової та основної НЛП курсантів, відповідно.

На вербальному рівні правило, описане виразом (1), може бути сформульоване наступним чином: надання вищого пріоритету 3 альтернативних варіантів такому типу НТЛ, який максимально пристосований для вирішення задач базової НЛП (виважено, до початкової та основної), має задані бойові властивості та вартісні оцінки витрат на забезпечення його життєвого циклу, що не перевищують задані обсяги, а термін служби - забезпечує використання НТЛ на протязі заданого періоду часу. Критерії (2) та (3) описують наступне правило: з множини альтернативних варіантів типів НТЛ кращим $є$ той, у якого значення узагальнених показників пристосованості до виконання задач початкової та основної НЛП курсантів, а також значення узагальнених показників бойових властивостей $є$ не меншими, ніж визначений для їх значень рівень, термін служби забезпечує використання НТЛ за призначенням на протязі заданого періоду часу, а узагальнені витрати ресурсів на життєвому циклі виробу повітряного судна є мінімальними.

Як вже відмічалося, для описання властивостей НТЛ, що характеризують ступінь його пристосованості до виконання задач НЛП навчаємих, запропоновано введення узагальненого показника $K_{\text {нлn }}$ та часткових узагальнених показників ступеню придатності НТЛ до виконання задач складових програм та груп вправ курсу НЛП курсантів. Такі показники вводяться за аналогією відомого узагальненого показника бойових властивостей тактичного літака коефіцієнту бойового потенціалу, як відношення ступеню придатності НТЛ для забезпечення НЛП навчаємих в базовій підготовці та їх складових програм, до ступеню такої ж придатності обраного за еталон НТЛ або НТЛ.

В загальному випадку кожна вправа будь-якої програми передбачає виконання декількох польотів, які, в свою чергу, розподіляються на ряд елементів польоту. Під час аналізу змісту вправ можна з'ясувати однотипні вправи, які складаються з однакових або схожих елементів польоту, і такі вправи доцільно об'єднати у відповідну групу. За підсумками аналізу можна визначити сукупність груп вправ, на які може бути розподілена кожна програма курсу 
НЛП. Це надає змоги здійснити декомпозицію змістовної частини всіх вправ в межах кожної програми курсу НЛП, яка буде максимально пристосованою для подальшого дослідження відомими та апробованими на практиці методами системного аналізу.

За розробленою методикою на першому рівні декомпозиції курсу льотної підготовки курсантів визначається важливість результату проходження курсантом кожної програми, яка описується ваговим внеском даної програми (в загальному випадку $w$-ї $з$ всіх $W$ можливих програм курсу НЛП) у результат всієї льотної підготовки навчаємих $\left(\alpha_{w}\right)$. Для цього рівня пропонується ввести сукупність узагальнених показників ступеню пристосованості НТЛ до забезпечення проходження навчаємим кожної програми $K_{w}$, як часткових узагальнених показників.

На другому рівні декомпозиції для кожної програми курсу НЛП визначаються групи вправ (або їх споріднених елементів), успішне освоєння яких вносить певний вклад у оволодіння курсантом необхідними навичками, та який може бути оціненим ваговим внеском $\beta_{w f}$. На цьому рівні ієрархії узагальнених показників ступеню пристосованості НТЛ до НЛП навчаємих пропонується ввести часткові узагальнені показники другого рівня - $K_{w f}$, які характеризують, відносно властивостей обраного еталону, ступінь пристосованості НТЛ до забезпечення виконання курсантом $f$-ї групи вправ у w-й програмі курсу НЛП.

На третьому рівні декомпозиції, в межах кожної програми курсу для кожної групи вправ (їх елементів) визначається сукупність факторів (ТTX НТЛ), значення яких впливають на якість виконання курсантом відповідних груп вправ. Для кожного 3 цих факторів визначається його важливість в цій групі вправ в даній програмі курсу, що оцінюється відповідним ваговим внеском $\gamma_{m w f}$.

Для всіх без виключення рівнів ієрархії вимагається, щоб сума вагових коефіцієнтів всіх факторів в межах одного й того ж рівня дорівнювала одиниці.

При визначенні всіх значень вагових внесків всіх програм, всіх груп вправ та всіх факторів (ТTХ НТЛ), можна побудувати узагальнений показник ступеню пристосованості НТЛ до забезпечення виконання задач як базової НЛП взагалі, так й до виконання окремих іiі програм і груп вправ, як сукупність кваліметричних моделей навчальних властивостей НТЛ. Такі моделі являють собою формалізовані залежності узагальненого показника ступеня пристосованості літака до виконання задач НЛП від значень визначаючих ТТХ НТЛ та будуються як:

-для часткових узагальнених показників другого рівня ієрархії (частковий показник пристосованості літака до виконання кожної $f$-ї групи вправ у $w$-й групи курсу НЛП):

$$
K_{w f}=\sum_{m=1}^{M_{w f}} \gamma_{m w f} x_{m w f},
$$

де $x_{m w f}-m-$ тактико-технічні характеристики

(TTX) $з$ факторного простору $f$-ї групи вправ у $w$-й програмі курсу НЛП ємністю $M_{w f}$ ТTХ;

- для часткових узагальнених показників першого рівня ієрархії (частковий показник пристосованості літака до виконання задач $w$-й програмі курсу НЛП ємністю $F_{w}$ груп вправ):

$$
K_{w}=\sum_{f=1}^{F_{w}} \beta_{w f} K_{w f}=\sum_{f=1}^{F_{w}} \beta_{w f} \sum_{m=1}^{M_{w f}} \gamma_{m w f} x_{m w f} ;
$$

- для узагальненого показника нульового рівня ієрархії (показника пристосованості літака до виконання задач всього курсу базової НЛП на реактивному літаку ємністю $W$ програм):

$$
\begin{aligned}
K_{w} & =\sum_{w=1}^{W} \alpha_{w} K_{w}=\sum_{w=1}^{W} \alpha_{w} \sum_{f=1}^{F_{w}} \beta_{w f} K_{w f}= \\
& =\sum_{w=1}^{W} \alpha_{w} \sum_{f=1}^{F_{w}} \beta_{w f} \sum_{m=1}^{M_{w f}} \gamma_{m w f} x_{m w f} .
\end{aligned}
$$

За вищезазначеною методикою було проведено аналіз поставлених задач чинного курсу базової НЛП навчаємих на реактивному НТЛ типу Л-39С 3 метою побудови ієрархічної структури узагальнених показників ступеню пристосованості НТЛ до вирішення навчальних задач та обгрунтування вибору ТТХ НТЛ для побудови факторного простору відповідних кваліметричних моделей. Сформована в результаті такого аналізу структура факторного простору кваліметричних моделей наведена на рис. 2. Зв'язки між елементами декомпозиції на другому рівні та факторами третього рівня ієрархії показано відповідними лініями. При цьому, факторні підпростори ТТХ НТЛ, на яких планується побудова кваліметричних моделей споріднених груп вправ (виконання зльоту і посадки, освоєння техніки пілотування) на другому рівні ієрархії, для початкової та для основної підготовки за змістом наборів ТTX співпадають. Побудована у відповідності до вищенаведеної декомпозиції ієрархічна структура узагальнених показників ступеню пристосованості НТЛ до забезпечення вирішення задач базової НЛП наведена на рис. 3 .

Таким чином, кваліметричні моделі властивостей навчального літака, що визначають ступінь його придатності до забезпечення задач базової навчальної льотної підготовки на другому рівні побудованої iєрархії, в загальному вигляді, будуть описуватися відповідними математичними функціями відповідних узагальнених показників від значень відповідних тактико-технічних характеристик, конкретний вигляд яких $\epsilon$ невідомим та який потрібно встановити для груп вправ, пов'язаних з навчанням зльоту у початковій та основній НЛП: 


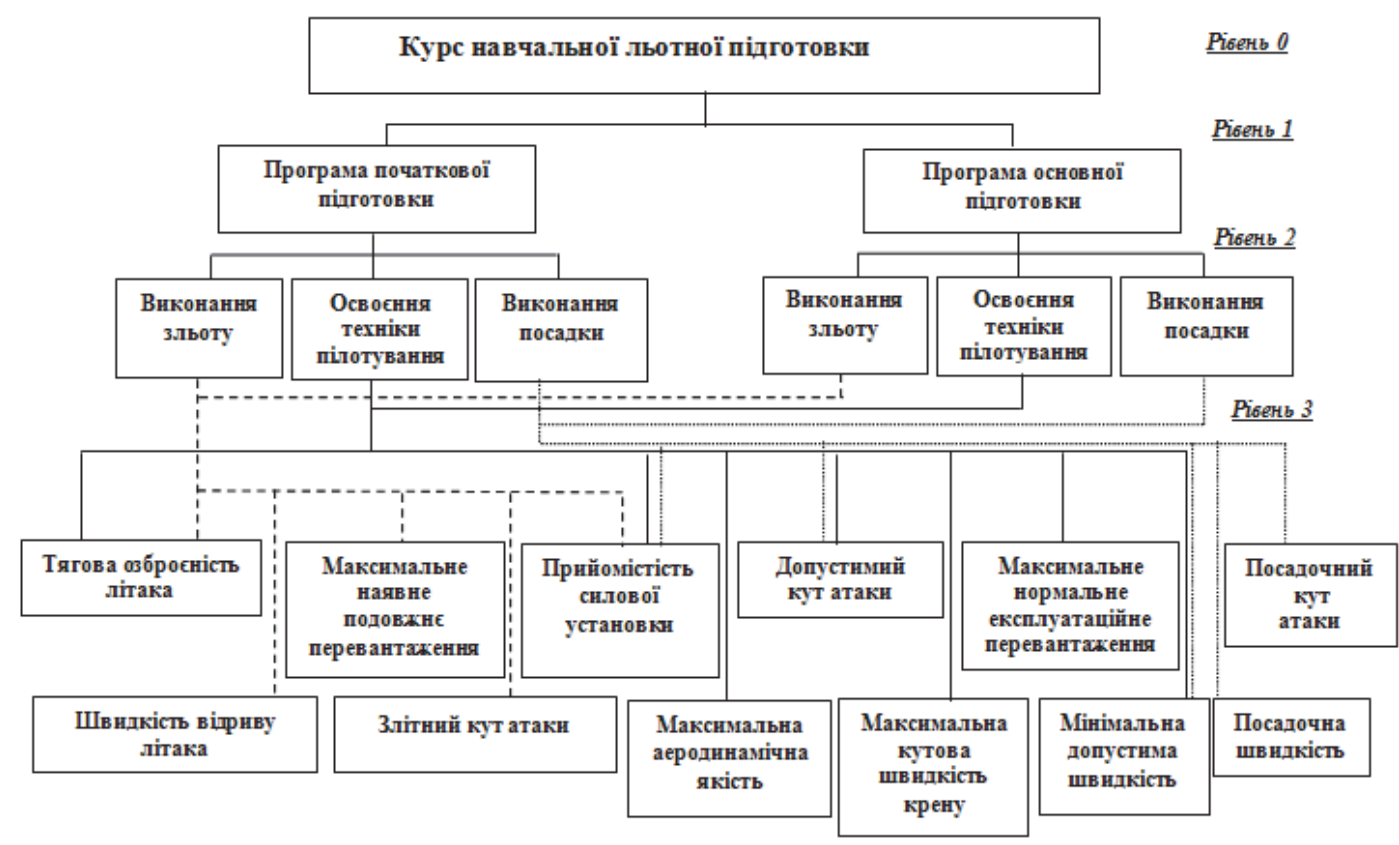

Рис. 2. Ієрархічна структура факторного простору, що обумовлює ступінь пристосованості НТЛ до забезпечення вирішення задач базової навчальної льотної підготовки Джерело: розроблено автором.

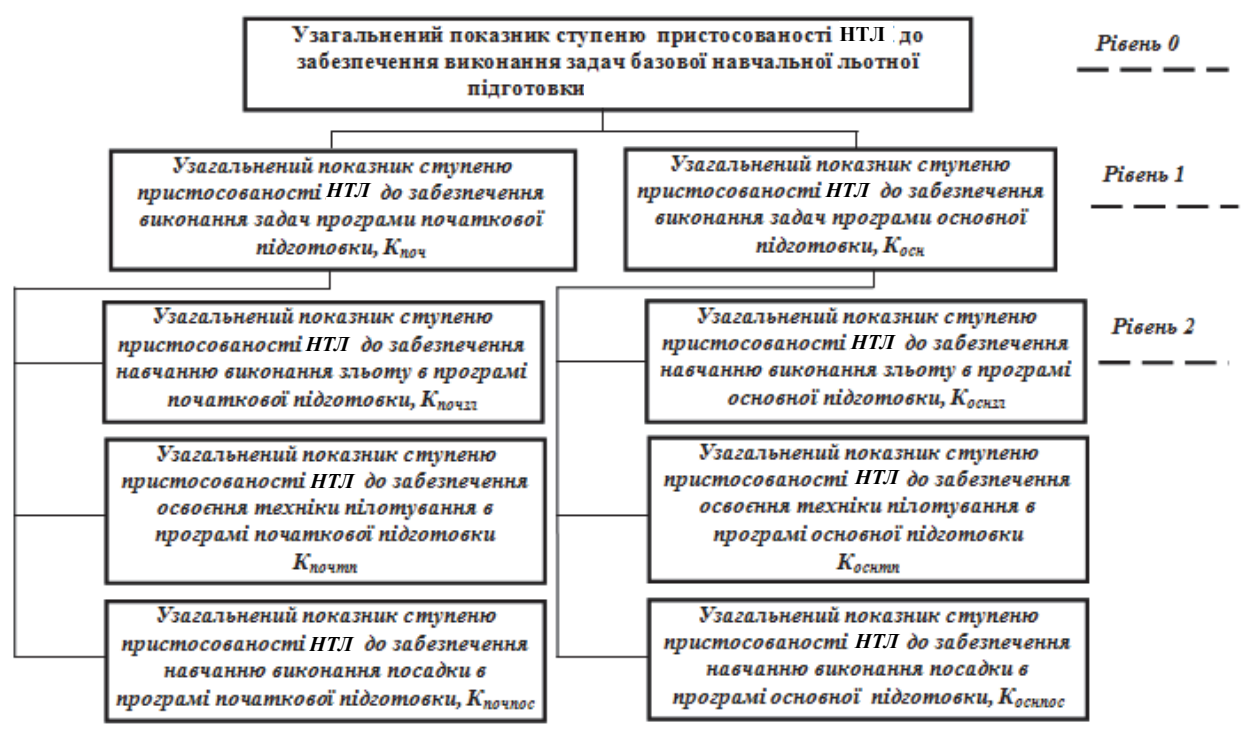

Рис. 3. Ієрархічна структура узагальнених показників ступеню пристосованості НТЛ до забезпечення вирішення задач базової НЛП

Джерело: розроблено автором.

$$
\begin{aligned}
& K_{\text {почзл }}=f_{\text {поч }}\left(\mu, v_{\text {відр }}, n_{x}, \alpha_{3 л}, t_{\text {nрсy }}\right), \\
& K_{\text {оснзл }}=f_{\text {осн }}\left(\mu, v_{\text {вiдp }}, n_{x}, \alpha_{3 л}, t_{n p c y}\right) ;
\end{aligned}
$$

- для груп вправ, пов'язаних з освоєнням техніки пілотування у початковій та основній НЛП:

$$
\begin{aligned}
& K_{\text {nочтn }}= \\
& =\phi_{\text {nоч }}\left(\omega_{x}, n_{x}, t_{n p c y}, \alpha_{\partial o n}, v_{\min \partial o n}, K_{\max }, \mu, n_{y \max }^{e}\right) ; \\
& K_{\text {ocнmn }}= \\
& =\phi_{\text {ocH }}\left(\omega_{x}, n_{x}, t_{n p c y}, \alpha_{\partial o n}, v_{\min \partial o n}, K_{\max }, \mu, n_{y \max }^{e}\right) ;
\end{aligned}
$$


крену; $\alpha_{\partial о n}-$ максимальний допустимий кут атаки; $v_{\min }$ доn - мінімальна допустима швидкість польоту; $K_{\max }$-максимальна аеродинамічна якість планеру; $n_{y \max }^{e}$ - максимальне експлуатаційне нормальне перевантаження; $\alpha_{\text {пос }}-$ посадочний кут атаки; $v_{\text {пос }}$ - посадочна швидкість.

Для формалізації складової витрат ресурсів в критеріях (1), (2) та (3) запропоновано використання відомого виразу для оцінювання питомих узагальнених витрат, що припадають на рік експлуатації та використання НТЛ за призначенням, враховуючи закупівлю серійного виробу:

$$
\overline{S_{1}} \approx(2,22 \ldots 2,5) C_{1} \frac{1}{T_{c л}}
$$

де $C_{1}$ - ціна одного серійного літального апарату; $T_{c л}$ - призначений термін служби НТЛ (в роках).

Дані коефіцієнти в подальшому враховані в кваліметричній моделі порівняльного оцінювання повітряних суден за ступенем пристосованості до виконання завдань по навчанню льотного складу.

\section{Висновки}

Таким чином сформовані критерії для порівняльного оцінювання НТЛ різних типів за ступенем пристосованості до виконання задач за призначенням, система показників, на яких ці критерії побудовано, та відпрацьовані методичні підходи до їх формалізації в сукупності створюють передумови для розробки удосконаленої методики порівняльного оцінювання повітряних суден різних типів. Обгрунтований варіант створення методики порівняльного оцінювання різних типів повітряних суден на етапах планування розвитку парку навчальної авіаційної техніки. Розроблено сукупність критеріїв вибору типу та показників для оцінювання ступеня пристосованості повітряного судна до вирішення завдань навчальної льотної підготовки. Обгрунтований факторний простір для розробки кваліметричних моделей на основі аналізу світового досвіду використання повітряних суден для навчальної льотної підготовки. Інноваційний підхід визначення коефіцієнтів для кваліметричних моделей дозволило підвищити ефективність оцінювання різних типів повітряних суден на етапах планування розвитку парку навчальної авіаційної техніки.

\section{Список літератури}

1. Нор П.І. Анализ развития учебно-тренировочных самолетов с турбореактивными двигателями / П.І. Нор // Наука і техніка Повітряних Сил Збройних Сил України. - 2010. - № 1(3). - С. 11-19.

2. Брахман Т.Р. Многокритериальность и выбор альтернативы в технике / Т.Р. Брахман. - М.: Радио и связь, 1984. $-288 \mathrm{c}$.

3. Єфіменко В.А. Основні технічні показники оцінки ефективності парків озброєння та військової техніки Збройних Сил / В.А. Єфіменко, П.І. Нор, А.Ю. Гупало // Зб. наук. праць ЦНДІ ОВТ ЗС України. - 2012. - Вип. 34. C. 87-98.

4. Демидов Б.А. Методы военно-научных исследований / Б.А. Демидов. - Х.: ВИРТА ПВО, 1989. - 594 с.

5. Демидов Б.А. Системная методология планирования развития, предпроектных исследований и внешнего проектирования вооружения и военной техники / Б.А. Демидов. - К.: Стилос, 2011. -464 с.

6. Фомин М.В. Метод двухуровневой оперативной сравнительной оценки боевой эффективности ударных авиационных комплексов / М.В. Фомин, Д.П. Спицин, М.С. Мухаметдинов // НММ в/ч 48230 “Методы обоснования требований к винтокрылым АК военного назначения". - М.: в/ч 48230, 1991. - С. $22-28$.

7. Азгальдов Г.Г. Количественная оценка качества продукции - квалиметрия / Г.Г. Азгальдов. - М.: Знание, 1986. $-365 \mathrm{c}$.

8. Єланський О.В. Оцінка досконалості авіаційного навчально-бойового комплексу на попередніх етапах його проектування або подальшої модернізації / О.В. Сланський // Системи озброєння і військова техніка. - 2014. - № 3. C. 33-36.

9. Кваліметричні моделі ступеню придатності навчально-бойового літака до використання в базовій навчальній льотній підготовці курсантів / О.Б. Леонтьєв, В.П. Срошенко, М.В. Науменко, І.Б. Ковтонюк // Наука і техніка Повітряних Сил Збройних Сил України. - 2019. - № 2(35). - С. 79-87. https://doi.org/10.30748/nitps.2019.35.10.

10. Нейвинский В.А. Перспективы производства за рубежом учебно-тренировочных самолетов / В.А. Нейвинский // Зарубежное военное обозрение - 2009. - № 12. - С. 61-65.

11. Нейвинский В.А. Итальянский учебно-тренировочный самолет / В.А. Нейвинский // Зарубежное военное обозрение. - 2009. - № 10. - С. 59-62.

12. Ильин В.Е. Боевые самолеты зарубежных стран XXI века / В.Е. Ильин. - М.: Издательство АСТ, 2000. - 192 с.

13. Barannik V. The positional structural-weight coding of the binary view of transformants / V. Barannik, A. Krasnorutskiy, A. Hahanova // East-West Design \& Test Symposium, 2013. - P. 1-4. 
Відомості про автора:

Срошенко Валерій Петрович

кандидат технічних наук

викладач кафедри Харківського національного

університету Повітряних Сил ім. І. Кожедуба,

Харків, Україна

https://orcid.org/0000-0003-3175-6444
Information about the author:

\author{
Valerii Yeroshenko \\ Candidate of Technical Sciences \\ Instructor of Ivan Kozhedub Kharkiv National \\ Air Force University, \\ Kharkiv, Ukraine \\ https://orcid.org/0000-0003-3175-6444
}

\title{
МЕТОДИКА ВЫБОРА КОЭФФИЦИЕНТОВ ДЛЯ ПОСТРОЕНИЯ КВАЛИМЕТРИЧЕСКОЙ МОДЕЛИ ВЫБОРА ВОЗДУШНОГО СУДНА ДЛЯ УЧЕБНОЙ ЛЕТНОЙ ПОДГОТОВКИ
}

\author{
В.П. Ерошенко
}

Раскрыта методика разработанного научно-методического аппарата оценки степени пригодности конкретного типа воздушного судна к решению задач учебной летной подготовки, и приведено обоснование выбора типа летательного аппарата из имеюшихся возможных альтернатив. Предлагается методика выбора коэффициентов для построения метода сравнительной оченки показателей свойств учебно-тренировочных самолетов. Обоснован вариант создания методики выбора рационального типа учебно-тренировочного самолета для замены существующего парка воздушных судов авиационных частей на основе сравнительной оценки альтернативных вариантов образцов авиационной техники на мировом рынке авиационной промышленности.

Ключевые слова: воздушное судно, квалиметрические модели, ресурс, учебный самолет, летная подготовка.

\section{THE COEFFICIENT-SELECTION METHOD FOR THE DEVELOPMENT OF THE AIRCRAFT CHOICE QUALIMETRIC MODEL FOR FLIGHT TRAINING}

\author{
V. Yeroshenko
}

It has been developed the methodological apparatus for assessing the degree of suitability of a particular type of aircraft to meet the challenge of the flight training, and for providing the rationale for choosing a type of aircraft among the available possible alternatives. It has been substantiated the peculiarity of the pilots' training procedures for flying the combat aircraft, which are in operational service, and the specificity of selection of the optimal variant of the aircraft for the flight training in the existing aviation industry of the State Enterprises of Ukraine, as well as foreign-manufactured aircraft. It has been submitted the hierarchical structure of the factor space, which specifies the degree of adaptation of the training aircraft to ensure the accomplishment of the objectives of the flight crews' basic flight training. It has been introduced the generalized criteria hierarchical structure of the training aircraft adaptation degree for the accomplishment of the basic flight training objectives. It has been suggested the coefficient selection method for creating a characteristics comparative analysis method for the trainer aircraft and combat-capable trainer aircraft. It has been proposed the model of selecting a rational type of the combat-capable trainer aircraft to replace the existing fleet of aircraft on the basis of the comparative evaluation of the alternative models of aircraft in the world arms market. The developed criteria for the comparative evaluation of the different types of aircraft according to the degree of adaptation to the tasks, the set of characteristics on which these criteria are based, and the tested methodological approaches to their formalization together create the prerequisites for developing the improved procedure of the comparative evaluation of the different types of aircraft. It has been proved the method of the comparative evaluation of the various types of aircraft at the planning stage of the trainer aircraft park development. It has been developed a set of criteria for selecting the aircraft type and characteristics for assessing the degree of suitability to accomplishment of the flight training objectives. The well-reasoned factor space for the qualimetric models development based on the analysis of the world experience in the use of aircraft for the flight training. The innovative approach to determining the coefficients for the qualimetric models has increased the efficiency of evaluating the different types of aircraft at the planning stage of the training aircraft fleet development.

Keywords: aircraft, qualimetric models, resource, training aircraft, flight training. 